BIOKEMISTRI 19(1):9-15 (June 2007)

This article is downloadable online in PDF

format at http://www.bioline.org.br/bk

Printed in Nigeria
An international journal published by the

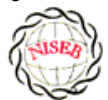

OVigerian Society for E̊xperimental \&Siology

\title{
Synthesis, characterization and antibacterial activity of aspirin and paracetamol- metal complexes
}

\author{
Amudat LAWAL and Joshua A. OBALEYE* \\ Department of Chemistry, Faculty of Science, University of Ilorin, Ilorin, Nigeria
}

Received 27 December 2006

MS/No BKM/2006/040, @ 2007 Nigerian Society for Experimental Biology. All rights reserved.

\begin{abstract}
Novel complexes of $\mathrm{Co}$ (11), $\mathrm{Ni}$ (11) and $\mathrm{Fe}$ (111) with aspirin and paracetamol have synthesized and characterized using infrared, electronic and Hnmr spectral, melting point and conductivity measurements. The two ligands have been found to act as bidentate chelating agents. Aspirin complexes coordinate through the carbonyl oxygen of the carboxyl and the ester groups, while paracetamol complexes coordinate through the oxygen of the hydroxyl and the amide groups. Antibacterial screening of the complexes against Bacillus substilis, Serratia species and Escherichia coli, was also investigated. The metal complexes were found to have varied degree of inhibitory effect against the bacteria.
\end{abstract}

.Keywords: Aspirin, Paracetamol, Metal Complexes, Antibacterial Activity

*To whom correspondence may be addressed, E-mail: jobaleye@ yahoo.com, amudatlawal@ yahoo.com Tel: +234-8033582048 


\section{INTRODUCTION}

Aspirin is a derivative of salicylic acid. It has analgesic, anti-inflammatory and antipyretic actions and inhibits prostaglandrin synthetase ${ }^{1}$ while paracetamol is a derivative of 4aminophenol which also has analgesic and antipyretic action ${ }^{2}$. Paracetamol is useful in the treatment of pain such as headache, toothache, rheumatism and neuralgia ${ }^{2}$.

However, it is known that some drugs act via chelation or by inhibiting metalloenzymes but for most of the drugs that act as potential ligands, a lot of studies are being carried out to ascertain how metal binding influences the activities of the drugs ${ }^{3}$. Although, in 1987, AbuEl-Wafa $e t a l^{4}$ reported the synthesis of Co(ii), $\mathrm{Ni}(\mathrm{ii})$ and $\mathrm{Fe}(\mathrm{ii})$ complexes of metformin(L), also an analgesic, on the basis of analytical data obtained, the prepared complexes were formulated as $\mathrm{ML}_{2}$.

Metal complexes are gaining increasing importance in the design of drugs on coordination with a metal. This has led to lots of study on metal drug complexes.

Therefore, it was considered necessary to have some other analgesic drug-metal complexes, due to their chemotherapeutic properties. We hereby report the synthesis, characterization and antibacterial activity studies of novel transition metal complexes of aspirin and paracetamol.

\section{MATERIALS AND METHODS}

All the chemicals were reagent grade and used as commercially obtained (Aldrich, BDH) without further purification.

Aspirin and paracetamol were obtained from Rajrab Pharmaceutical company Ltd., Ilorin, Kwara State. Nigeria.

The melting points of the ligands and the complexes were carried out using Gallenkemp melting apparatus.

The thin layer chromatography of the complexes was run using solvent mixture of ethanol, acetone and petroleum ether in the 7:2:1 mole ratio.

The molar conductively of the ligands and the complexes in methanol at room temperature $\left(25 \pm 0.1^{0} \mathrm{C}\right)$ were made on WTW Conductometer Bridge with a cell constant of $0.82 \mathrm{~cm}^{-1}$. The IR spectral were recorded in solid state as $\mathrm{KBr}$ pellets using Buck-Scientific M 500 model infrared spectrophotometer form $4000 \mathrm{~cm}^{-1}$ to $600 \mathrm{~cm}^{-1}$

The uv/visible spectra were made on $\operatorname{Sp} 8-400$ uv/visible spectrophotometer using methanol as solvents. The metal content of the complexes were determined by using an SP9, atomic absorption spectrophotometer with PM 8251 simple-pen recorder.

The proton $\mathrm{nmr}$ spectra of the ligands and the complexes were obtained on Bruker AC 200/300 spectrometer using deuterated chloroform as solvents.

\section{Evaluation of antibacterial activity}

The antibacterial activity of the test compounds was assayed against three bacteria: Bacillus Subtilis, Serratia Species and Escherichia coli.

The antibacterial activity of the compounds was determined as reported by Abd E1-Wahab and E1-sarrag 5 .

The antibacterial activity was determined on the seeded nutrient agar on which $0.9 \mathrm{~cm}$ diameter wells punched. Different concentrations $(0.1 \%$ and $1.0 \% \mathrm{w} / \mathrm{v}$ ) of sterile filtered solutions of the ligands and the complexes were made using methanol as solvents, $0.1 \mathrm{~m} 1$ of each concentration was applied into the wells and incubated at $37^{\circ} \mathrm{C}$ for one to three days.

The antibacterial activity was estimated on the basis of the size of inhibition zone formed around the well of the seeded agar plates and the inhibition growth in percentage was determined on the basis of the average diameter of bacterial colony on the growth medium to their respective controls as in the equation

$$
\% \text { Inhibition }=\frac{\mathrm{A}-\mathrm{B}}{\mathrm{A}} \times 100
$$


Where $A=$ Average diameter of bacterial growth on the control and $\mathrm{B}=$ Average diameter of bacterial growth on the test plate

\section{Synthesis of Aspirin-metal complexes}

The complexes were prepared by adding on aqueous solution of the hydrated metal chloride $(0.01 \mathrm{~mol})$ to an ethanolic solution of the ligand, Aspirin $(3.604 \mathrm{~g}, 0.02 \mathrm{~mol})$. The solution was refluxed with constant stirring for 3 hours. The complexes were recovered from their solutions and followed by washing with ethanol and dried in a desiccator.

\section{Synthesis of Paracetamol- metal complexes}

The preparation was similar to that of Aspirin metal complexes. An aqueous solution of hydrated metal chloride $(0.01 \mathrm{~mol})$ in ethanol $(10 \mathrm{ml})$ was added to an ethanolic solution of the ligand, paracetamol $3.032 \mathrm{~g}, \quad 0.02 \mathrm{~mol}$ ) the mixture was refluxed for 3 hours and left for about three weeks before complexation. The precipitated complex was removed by filtration and washed with ethanol and dried in a dessicator.

\section{RESULTS AND DISCUSSION}

The results of the analytical data, spectroscopic and antibacterial studies are presented in Tables $1-5$.

All the complexes were found to be stable. They are non-hygroscopic solids with low melting points. The molar conductance data for the metal complexes in methanol show non-electrolytic behavior in this solvent.

All the complexes synthesized were coloured. The coloured complexes obtained for iron (III) complexes $\left(d^{5}\right)$ were likely due to charge transfer from ligand to metal and vice versa.

Table 1: Analytical data and some physical properties of the complexes

\begin{tabular}{|c|c|c|c|c|c|c|}
\hline Compound & Colour & M.P $\left({ }^{0} \mathrm{C}\right)$ & $\begin{array}{c}\text { Yield } \\
\%\end{array}$ & $\begin{array}{l}\mathrm{M} \\
\%\end{array}$ & $\begin{array}{l}\text { Molar Conductance } \\
\Omega^{-1} \mathrm{~g} / \mathrm{dm}^{3}\end{array}$ & $\begin{array}{c}\text { Electronic Transition } \\
(\mathrm{nm})\end{array}$ \\
\hline Aspirin(asp) & Whitish & $138-140$ & - & - & $5.20 \times 10^{7}$ & 275,243 \\
\hline $\mathrm{Co}(\mathrm{Asp})_{2} \mathrm{Cl}_{2}$ & Brown & $122-124$ & 60.4 & $\begin{array}{l}12.10 \\
(12.02)\end{array}$ & $6.12 \times 10-5$ & $302,262,233$ \\
\hline $\mathrm{Ni}(\mathrm{Asp})_{2} \mathrm{Cl}_{2}$ & White & $118-120$ & 52.3 & $\begin{array}{l}10.98 \\
(10.27)\end{array}$ & $4.20 \times 10-5$ & $296,257,241$ \\
\hline $\mathrm{Fe}(\mathrm{Asp})_{2} \mathrm{Cl}_{3}$ & Black & $123-126$ & 51.2 & $\begin{array}{c}9.30 \\
(9.76)\end{array}$ & $1.52 \times 10-5$ & $297,265,235$ \\
\hline Paracetamol & Whitish & $168-170$ & - & - & $4.25 \times 10-7$ & 243 \\
\hline $\mathrm{Co}(\mathrm{Par})_{2} \mathrm{Cl}_{2}$ & Cream & $136-138$ & 73.9 & $\begin{array}{c}12.14 \\
(11.76)\end{array}$ & $2.43 \times 10-6$ & 245,220212 \\
\hline $\mathrm{Ni}(\mathrm{Par})_{2} \mathrm{Cl}_{2}$ & Light Pint & $144-146$ & 64.7. & $\begin{array}{r}13.59 \\
(13.75\end{array}$ & $1.94 \times 10-6$ & $248,218,210$ \\
\hline $\mathrm{Fe}(\mathrm{Par})_{2} \mathrm{Cl}_{3}$ & Black & $128-130$ & 54.3 & $\begin{array}{c}10.29 \\
(10.24)\end{array}$ & $1.65 \times 10-6$ & 238 \\
\hline
\end{tabular}

Table 2: Selected IR spectral assignment of aspirin (asp) and its metal complexes

\begin{tabular}{|c|c|c|c|c|}
\hline Aspirin $(\mathrm{cm}-1)$ & $\mathrm{Co}(\mathrm{Asp})_{2} \mathrm{Cl}_{2}\left(\mathrm{~cm}^{-1}\right)$ & $\mathrm{Ni}(\mathrm{Asp})_{2} \mathrm{Cl}_{2}\left(\mathrm{~cm}^{-1}\right)$ & $\mathrm{Fe}(\mathrm{Asp})_{2} \mathrm{Cl}_{3}\left(\mathrm{~cm}^{-1}\right)$ & Tentative Assignment \\
\hline $3776.3 \mathrm{~m}, \mathrm{~b}$ & $\begin{array}{l}3235.3 \mathrm{w} \\
3101.5 \mathrm{w}\end{array}$ & $\begin{array}{l}3235.3 \mathrm{~s}, \mathrm{~b} \\
3101.5 \mathrm{~m}\end{array}$ & $\begin{array}{l}3764.2 \mathrm{~s} \\
3235 \mathrm{w}, \mathrm{b}\end{array}$ & $\mathrm{O}-\mathrm{H}$ str \\
\hline $\begin{array}{l}1757.8 \mathrm{~s} \\
1675.6 \mathrm{v}, \mathrm{s}\end{array}$ & $\begin{array}{l}1745.7 \mathrm{~m}, \mathrm{~b} \\
1666.6 \mathrm{~s}, \mathrm{~b}\end{array}$ & $\begin{array}{l}1745.7 \mathrm{~m}, \mathrm{~b} \\
1666.6 \mathrm{v}, \mathrm{s}\end{array}$ & $\begin{array}{l}1754.7 \mathrm{~m} \\
1666.6 \mathrm{~s}\end{array}$ & $\begin{array}{l}\mathrm{C}=\mathrm{O} \text { of ester } \\
\mathrm{C}=\mathrm{O} \text { of } \\
\text { Carboxylic acid }\end{array}$ \\
\hline $\begin{array}{l}1374.7 \mathrm{~s} \\
1308.0 \mathrm{v} . \mathrm{s}\end{array}$ & $\begin{array}{l}1301.8 \mathrm{v} . \mathrm{s} \\
1247.2 \mathrm{~s}\end{array}$ & 1247.2 v.s & $\begin{array}{l}1393 \mathrm{~s}, \mathrm{~b} \\
1295.9 \mathrm{v}, \mathrm{s}\end{array}$ & $\begin{array}{l}\text { C-O str of } \\
\text { Carboxylic acid }\end{array}$ \\
\hline $\begin{array}{l}1095.2, \mathrm{~b} \\
1016.1 \mathrm{~m}, \mathrm{~b}\end{array}$ & $\begin{array}{l}1156.0 \mathrm{v}, \mathrm{s} \\
1028.2 \mathrm{~m}\end{array}$ & 1156.Os & $1156.0 \mathrm{~s}$ & C-O str of ester \\
\hline- & $669.6 \mathrm{~s}$ & $663.3 \mathrm{~s}, \mathrm{~b}$ & $663.44 \mathrm{~s}$ & $\begin{array}{l}\mathrm{M}-\mathrm{OH} \& \\
\mathrm{M}-\mathrm{O}=\mathrm{C}\end{array}$ \\
\hline
\end{tabular}


Table 3: Selected IR spectal assignment of pr/aracetamol (par) and its metal compexes

\begin{tabular}{|l|l|l|l|l|}
\hline Paracetamol (Par) & $\mathrm{Co}\left(\mathrm{Par}_{2} \mathrm{Cl}_{2}\right.$ & $\mathrm{Ni}^{(\mathrm{Par})_{2} \mathrm{C} 1_{2}}$ & $\mathrm{Fe}\left(\mathrm{Par}_{2} \mathrm{Cl}_{2}\right.$ & Tentaive Assignment \\
\hline & $3794.6 \mathrm{w}, \mathrm{b}$ & $3758.2 \mathrm{~b}$ & $3782.4 \mathrm{~m}, \mathrm{~b}$ & $\mathrm{O}-\mathrm{H} \&$ \\
$3785.2 \mathrm{~m}, \mathrm{~b}$ & $3320.3 \mathrm{~s}$ & $3429.8 \mathrm{w}, \mathrm{b}$ & $3691.2 \mathrm{w}, \mathrm{b}$ & $\mathrm{N}-\mathrm{H} \mathrm{str}$ \\
$3694.9 \mathrm{w}$ & $3162.3 \mathrm{w}, \mathrm{b}$ & $3320.3 \mathrm{~m}$ & $3630.4 \mathrm{w}, \mathrm{b}$ & \\
& $3707.5 \mathrm{w}, \mathrm{b}$ & $3162.3 \mathrm{w}$ & & \\
\hline $1625 \mathrm{~s}, \mathrm{~b}$ & $1612.0 \mathrm{~s}$ & $1612.0 \mathrm{~s}$ & $1617.9 \mathrm{~m}, \mathrm{~b}$ & $\mathrm{C}=\mathrm{O} \mathrm{str}$ \\
\hline- & $693.8 \mathrm{~s}$ & $681.7 \mathrm{~s}, \mathrm{~b}$ & - & $\begin{array}{l}\text { [M-OH] and } \\
\text { [M-O=C] }\end{array}$ \\
\hline
\end{tabular}

Table 4: HNMR Spectral Assignment of Aspirin (Asp) and Its Metal Complexes

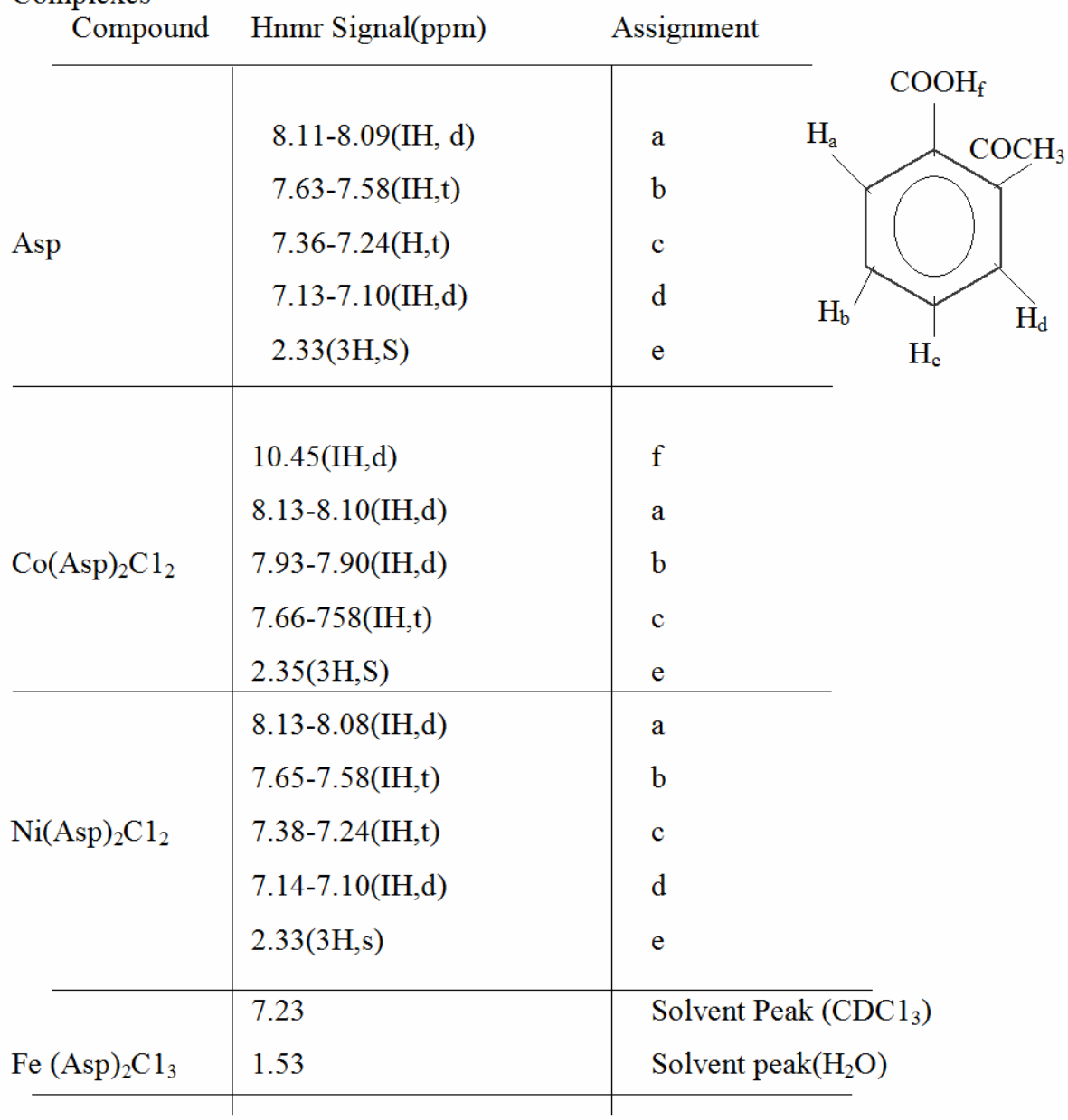

The selective infrared spectra assignment off free Aspirin and its complexes are given in Table 2. The assignments have been carried out based on comparison of the spectra data with of similar compounds ${ }^{6}$.

The absorption band at $3776.3 \mathrm{~cm}^{-1}$ in the spectrum of free Aspirin has been attributed to $\mathrm{O}-\mathrm{H}$ group. These bands undergo hypsochromic shift to $3235.3 \mathrm{~cm}^{-1}$ and $3101.5 \mathrm{~cm}^{-1}$ in the metal complexes. The shifting of these $(\mathrm{O}-\mathrm{H})$ stretching vibrational band provide evidence that this group is one of the coordination sites of Aspirin. This is also supported by broad bands at $294.9 \mathrm{~cm}^{1}, 852 \mathrm{~cm}^{-1}$ and $803.3 \mathrm{~cm}^{-1}$ attributed to $\mathrm{O}-\mathrm{H}$ bending ${ }^{6}$. The bands at $1460 \mathrm{~cm}^{-1}$ and $1417.5 \mathrm{~cm}^{-1}$ has been assigned to $\mathrm{C}=\mathrm{O}$ of ester and carboxylic acid respectively, these bands 
also undergo hypsochromic shift in the spectra of the complexes. The shifting of these $(\mathrm{C}=\mathrm{O})$ stretching bands provides evidence that this group is also one of the coordination sites of Aspirin.

The strong absorption bands at $1374.7 \mathrm{~cm}^{-1}$ and $1308 \mathrm{~cm}^{-1}$ have been attributed to $\mathrm{C}-\mathrm{O}$ stretching vibration of the carboxylic acid while the medium bands at $1095.2 \mathrm{~cm}^{1-}$ and $1016.1 \mathrm{~cm}^{-1}$ and $1016.1 \mathrm{~cm}^{-1}$ have been attributed to $\mathrm{C}-\mathrm{O}$ stretching vibration of the ester ${ }^{6}$.

The strong absorption bands between the ranges of $651.3 \mathrm{~cm}^{-1}$ on the spectra of the metal complexes which could not be traced to free Aspirin have been tentatively assigned to [M$\mathrm{OH}]$ and $[\mathrm{M}-\mathrm{O}=\mathrm{C}]$ stretch bands of the metal complexes ${ }^{7}$.

The IR spectra assignment of Paracetamol (Par) and its metal complexes are presented in Table 3.

The spectrum of free paracetamol was compared with the spectral of its metal complexes. The absorption bands at $3785.2 \mathrm{~cm}^{-1}$ and $3694.9 \mathrm{~cm}^{-1}$ of the free paracetamol have been assigned to $\mathrm{O}$ $\mathrm{H}$ and $\mathrm{N}-\mathrm{H}$ stretching vibrations. These bands have been shifted in the spectra of the metal complexes due to coordination.

The strong absorption bands at $1625.0 \mathrm{~cm}-1$ in the spectrum of free paracetamol has been assigned to $\mathrm{C}=\mathrm{O}$ stretching. These bands have been shifted in the spectra of the metal that this complexes. The shifting of $\mathrm{C}=\mathrm{O}$ group provide evidence of coordination through this group ${ }^{7}$. The strong absorption bands at $693.8 \mathrm{~cm}^{-1}$ and $681.7 \mathrm{~cm}^{-1}$ in the spectra of the $\operatorname{Co}(\operatorname{Par})_{2} \mathrm{Cl}_{2}$ and $\mathrm{Ni}$ (Par $)_{2} \mathrm{Cl}_{2}$ complexes which could not be traced to free paracetamol have been tentatively assigned to $[\mathrm{M}-\mathrm{O}=\mathrm{C}]$ and $[\mathrm{M}-\mathrm{OH}]$ stretch bands of the metal complexes ${ }^{7}$.

The H NMR signals of aspirin and it metal complexes are presented in Table 4. The multiplicity and integral values of the proton signals support the structure of the ligand. The assignment of the protons is supported by highly reduced intensity of the proton signals after deuterium exchange.
The $\mathrm{Fe}(\mathrm{Asp})_{2} \mathrm{Cl}_{3}$ complex was insoluble in $\mathrm{CDCl}_{3}$, therefore the signals obtained were mainly the solvent peaks ${ }^{8}$.

By considering all the above analytical and spectroscopic data and in the absence of X-ray crystallographic data. The structures tentatively proposed for the complexes are show in Figures I and II.

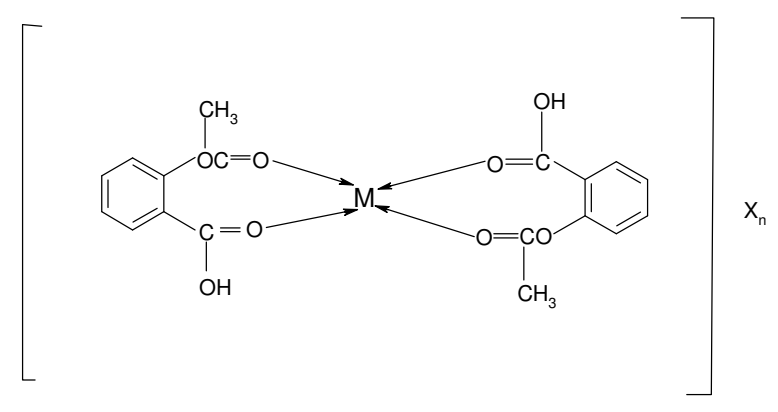

Fig I: Proposed structure for $M(A s p)_{2} X_{n}$

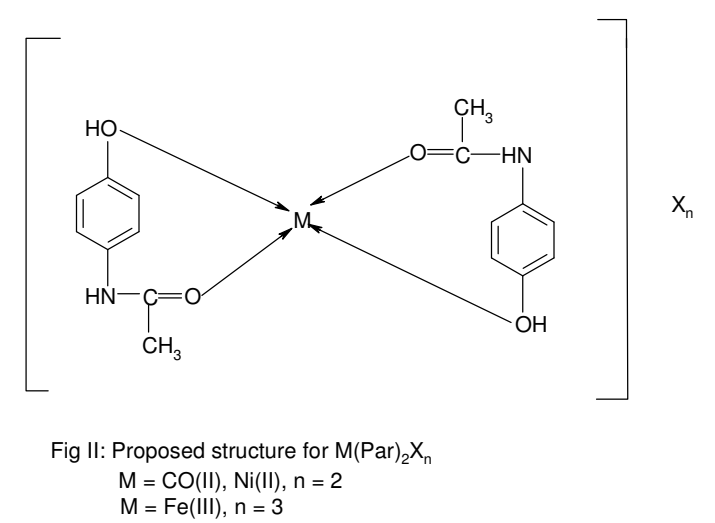

The aspirin complexes, $\mathrm{M}(\mathrm{Asp})_{2} \mathrm{X}_{\mathrm{n}}$ have insignificant effect on serratia and $E$. coli species at both concentrations (Table 5). $\mathrm{Co}$ (Asp) ${ }_{2} \mathrm{Cl}_{2}$ have the greatest inhibitory effect against Bacillus subtilis while $\mathrm{Ni}(\mathrm{Asp})_{2} \mathrm{Cl}_{2}$ have the lowest inhibitory effect. At $1.0 \%$ concentration, Aspirin metal complexes show higher activity than the original aspirin.

The paracetamol complexes, $\mathrm{M}(\mathrm{Par})_{2} \mathrm{Xn}$ have insignificant effect on serratia and Bacillus subtilis species at both concentration. $\mathrm{Fe}(\mathrm{Par})_{2} \mathrm{Cl}_{3}$ have the greatest inhibitory effect against $\mathrm{E}$. coli while $\mathrm{Ni}(\mathrm{Par})_{2} \mathrm{Cl}_{2}$ have the lowest inhibitory effects at both concentration. The 
Table 5: Result of antibacterial test

\begin{tabular}{|c|c|c|c|c|c|c|c|c|c|}
\hline Compound & Concentration & $\begin{array}{l}\text { Serrati } \\
\text { SP }\end{array}$ & & $\begin{array}{l}\text { Baci } \\
\text { SP }\end{array}$ & & & $\begin{array}{l}\text { Esc } \\
\text { Co }\end{array}$ & heric & \\
\hline $\begin{array}{l}\text { Asp } \\
\mathrm{Co}(\mathrm{Asp})_{2} \mathrm{c}_{2} \\
\mathrm{Ni}(\mathrm{Asp})_{2} \mathrm{Cl}_{2} \\
\mathrm{Fe}(\mathrm{Asp})_{2} \mathrm{Cl}_{3}\end{array}$ & $0.1 \%$ & $\begin{array}{ll}- & - \\
- & - \\
- & - \\
- & -\end{array}$ & - & $\begin{array}{l}0 \\
50 \\
32 \\
45\end{array}$ & $\begin{array}{l}0 \\
51 \\
32 \\
47\end{array}$ & $\begin{array}{c}0 \\
50 \\
\\
34 \\
\\
48\end{array}$ & $\begin{array}{l}- \\
- \\
- \\
-\end{array}$ & $\begin{array}{l}- \\
- \\
-\end{array}$ & $\begin{array}{l}- \\
- \\
-\end{array}$ \\
\hline $\begin{array}{l}\text { Asp } \\
\mathrm{Co}(\mathrm{Asp})_{2} \mathrm{Cl}_{2} \\
\mathrm{Ni}(\mathrm{Asp})_{2} \mathrm{Cl}_{2} \\
\mathrm{Fe}(\mathrm{Asp})_{2} \mathrm{Cl}_{3}\end{array}$ & $1.0 \%$ & $\begin{array}{ll}- & - \\
- & - \\
- & - \\
- & -\end{array}$ & - & $\begin{array}{l}28 \\
90 \\
52 \\
85\end{array}$ & $\begin{array}{l}28 \\
94 \\
55 \\
82\end{array}$ & $\begin{array}{l}30 \\
96 \\
57 \\
80\end{array}$ & $\begin{array}{l}- \\
- \\
- \\
-\end{array}$ & $\begin{array}{l}- \\
- \\
-\end{array}$ & - \\
\hline $\begin{array}{l}\text { Par } \\
\mathrm{Co}(\mathrm{Par})_{2} \mathrm{Cl}_{2} \\
\mathrm{Ni}(\mathrm{Par})_{2} \mathrm{Cl}_{2} \\
\mathrm{Fe}(\mathrm{Par})_{2} \mathrm{Cl}_{3}\end{array}$ & $0.1 \%$ & $\begin{array}{ll}- & - \\
- & - \\
- & - \\
- & - \\
- & -\end{array}$ & - & $\begin{array}{l}- \\
- \\
- \\
-\end{array}$ & $\begin{array}{l}- \\
- \\
- \\
-\end{array}$ & $\begin{array}{l}- \\
-\end{array}$ & $\begin{array}{l}0 \\
25 \\
22 \\
30\end{array}$ & $\begin{array}{c}0 \\
27 \\
22 \\
31\end{array}$ & $\begin{array}{r}0 \\
27 \\
24 \\
30\end{array}$ \\
\hline $\begin{array}{l}\text { Par } \\
\mathrm{Co}(\mathrm{Par})_{2} \mathrm{Cl}_{2} \\
\mathrm{Ni}(\mathrm{Par})_{2} \mathrm{Cl}_{2} \\
\mathrm{Fe}(\mathrm{Par})_{2} \mathrm{Cl}_{3}\end{array}$ & $1.0 \%$ & $\begin{array}{ll}- & - \\
- & - \\
- & - \\
- & -\end{array}$ & - & $\begin{array}{l}- \\
- \\
- \\
-\end{array}$ & $\begin{array}{l}- \\
- \\
- \\
-\end{array}$ & - & $\begin{array}{l}18 \\
55 \\
50 \\
60\end{array}$ & $\begin{array}{c}20 \\
58 \\
52 \\
62\end{array}$ & $\begin{array}{c}18 \\
60 \\
55 \\
64\end{array}$ \\
\hline
\end{tabular}

paracetamol complexes also show higher activity than the ligand ${ }^{9}$.

\section{Acknowledgement}

The authors are grateful to Rajrab Pharmaceutical Company limited, Ilorin, Kwara State, Nigeria for the supply of the ligands.

\section{REFERENCES}

1.British Pharmaceutical Codex (1977) $11^{\text {th }}$ ed. Pharmaceutical Press, London, Pp 48 -54 .

2. Remington's Pharmaceutical Science (1970) $18^{\text {th }}$ ed., John Wiley Pub. Inc. New York.

3.Behrens, N. B., Diaz, G. M. and Goodgame, D.M.L (1986) Metal complexes of the antibiotics Nalidixic acid. Inorg. Chim. Acta. 125:21-264.

4.Abu-El-Wafa, S.M El-Rifs, M.A and Ahmed, F.H (1987) Formation of metformin complexes with some transition metal ions and their biological activity. Inorg. Chim. Acta. 136:127-131

5.Abu-El-Wahab, Z. H. and El-Sarrag, M. R. (2004) Derivatrive of phosphate schift base transition metal complexes: synthesis, studies and biological activity. Spec. Acta 60:271-277.

6.William, K. (1991) Organic Spectroscopy, $3^{\text {rd }}$ edition, Macmillan Education Ltd, London , 49-54, 60-75 
7.Nakamato, K (1970) Infrared Spectra of Inorganic and Coordination Compounds, $2^{\text {nd }}$ edition, John Wilely, New York, 166-219

8.Issa, A (2001) Synthesis, Characterization and Antimicrobial Activity of Metronidazole, Aspirin, Paracetamol and Tetracycline Metal Complexes. M.Sc Thesis, Department of Chemistry, University of Ilorin , Pp 50-98.

9.Obaleye, J.A Nde -aga,, J.B and Balogun , E.A (1997) Some Antimalarial drug-metal complexes, "Synthesis, characterization and in vivo evaluation against malarial parasite. Afr. J. Sci. 1:10-12 